\author{
Amedeo Giovanni Conte* \\ Università degli Studi di Pavia \\ Accademia Nazionale dei Lincei \\ Paolo Di Lucia** \\ Università degli Studi di Milano
}

\title{
PRAGMATIC AMBIGUITY: THE THETIC FUNCTION OF MODALITY
}

\author{
Bo on rzekł-i stało się, \\ On rozkazał - i stanęło. \\ For he spoke, and it was done; \\ he commanded, and it stood fast. \\ Psalm 33:6 \\ Im Anfang war die Tat. \\ Johann Wolfgang von Goethe
}

\begin{abstract}
The aim of this paper is to present an overview of the pragmatic aspects of ambiguity present in deontic sentences, which may have three pragmatic functions: a prescriptive or a descriptive or a constitutive function. This type of ambiguity is investigated on the lexical, phrasal, and sentential level. The discussion focuses on the deontic constructions of the German verb sollen and the English shall as they are used in legal texts. It also includes comments on the thetic function of the Latin imperative mood and the subjunctive mood.
\end{abstract}

\section{Keywords}

modality, deonticity, speech act, mood, ambiguity, pragmatics

\footnotetext{
* Università degli studi di Pavia

Strada Nuova 65, I-27100 Pavia, Italy

e-mail: conte@unipv.it

**Università degli Studi di Milano

Via Festa del Perdono 7, I-20122 Milano, Italy

e-mail: dilucia@fildir.unimi.it
} 


\section{Ambiguity of 'ambiguity': ambiguity of deontic sentences $v s$. ambiguity of deontic linguistic forms (modal verbs and verbal moods).}

\subsection{Pragmatic ambiguity of deontic sentences}

The pragmatic ambiguity of deontic sentences is a very well known phenomenon in speech acts theory. ${ }^{1}$ This phenomenon has been isolated by the German logician Christoph Sigwart [1830-1904]. Deontic sentences (the "ought"sentences) are subject to a double interpretation: they may be used to prescribe norms (prescriptive deontic sentences) or they may be used to describe norms (descriptive deontic sentences).

The thesis of the pragmatic ambiguity of a deontic sentence is developed independently of Sigwart by the Swedish philosopher Ingemar Hedenius [19081982].

Hedenius's distinction (1941) between äkta rättssatser ("authentic legal sentences") and oäkta rättssättser ("non-authentic legal sentences") is the starting point of Georg Henrik von Wright's interpretation of deontic logic (1963). In particular, G. H. von Wright [1916-2003] introduces the paradigm: “descriptively interpreted deontic sentence" vs. "prescriptively interpreted deontic sentence." G. H. von Wright writes:

The deontic sentences of ordinary language exhibit a characteristic ambiguity.
Tokens of the same type are used sometimes to enunciate a prescription (i.e., to
enjoin, permit or prohibit a certain action), sometimes again to express a proposition
to the effect that there is a prescription enjoining or permitting or prohibiting a
certain action.
(G. H. von Wright 1963: 105)

\subsection{Pragmatic ambiguity of deontic linguistic forms}

At a different level, a similar phenomenon of ambiguity in deontic language is to be found in many deontic linguistic forms. That is to say, many prima facie linguistic deontic forms are subject to a double interpretation.

This pragmatic ambiguity of prima facie deontic linguistic forms has been deeply explored by the German philosopher Herbert Spiegelberg [Straßburg/Strasbourg, 1904-St. Louis (U.S.A), 1990] in his deontic trilogy: Gesetz und Sittengesetz, 1935; Antirelativismus, 1935; Sollen und Dürfen,1937.

He seems to limit himself to analyzing the ambivalence of deontic linguistic

\footnotetext{
${ }^{1}$ Cf. Théorie des actes de langage, éthique et droit (edited by Paul Amselek), 1986.
} 
forms rather than considering the ambivalence of whole sentences. One might say that he remains below the threshold of the sentence.

\subsection{Pragmatic ambiguity of modal verbs vs. pragmatic ambiguity of} verbal moods

Pragmatic ambiguity can affect both verbs and moods, for example:

(i) the German modal verb 'sollen';

(ii) the English modal verb 'shall';

(iii) the Latin imperative mood;

(iv) the Latin subjunctive mood.

These four prima facie deontic linguistic forms can have not only a deontic sense, but also a thetic function, i.e. they can be used to constitute, to pose, and to create a non pre-existing state of affairs.

\section{Pragmatic ambiguity of modal verbs}

\subsection{The thetic function of the German modal verb 'sollen'.}

\subsubsection{The paradigm thetic vs. deontic.}

The German modal verb 'sollen' (which occurs in terms like "Sollnorm," "Sollsatz," "Sollsatzlogik," "Sollgeltung," "Sollverhalt," "Sollsachverhalt") has not only a deontic sense, but also a thetic function (under the interpretation that sense is a semantic notion, while function is a pragmatic one). For instance, in sentences like:

(1) "Buchstabe 'S' soll das Satzsubjekt bedeuten"

the verbal form soll has the function of constituting ("zum Bestehen bringen") a state of affairs:

soll hat die Funktion, einen Sachverhalt zum Bestehen zu bringen.

(Spiegelberg 1935: 74; 1958: 244).

Among sentences in which sollen is used in a thetic function, there are, e.g.: 
(2) Zwei Aussageformen $A$ und $B$ sollen äquivalent heißen, wenn " $A<\longrightarrow B$ " allgemeingültig ist. ${ }^{2}$

(3) Spigel der sachsen sal dis buch sin genant. ${ }^{3}$

(4) Das soll jetzt ein Haus sein. (In einem Spiel.) ${ }^{4}$

\subsubsection{Truth and validity}

\subsubsection{Theticity and truth}

Sentences in which sollen is used in a thetic function have a semantic peculiarity: they are non-apophantic sentences. Spiegelberg writes:

der ausgedrückte Gedanke erhebt keinen Anspruch auf Wahrheit, auf Deckung des Behaupteten mit einem tatsächlichen Sachverhalt.

(Spiegelberg 1935: 74; 1958: 244)

\subsubsection{Theticity and validity}

According to Spiegelberg, the paradigm case of sentences in which sollen has a thetic function is the legislative sentences. In his own words:

Noch klarer ist der Fall der normativen Festsetzung, besonders in der Form eines statuierenden Gesetzes. Denn eine solche Festsetzung entwirft nicht nur einen eigenartigen Sachverhalt, eine "Ordnung" oder Anordnung, sondern sie erteilt ihm zugleich eine eigentümliche Festigkeit, eine Seinsart die häufig auch als "Geltung" bezeichnet wird.

(Spiegelberg 1935: 74; 1958: 244)

\footnotetext{
${ }^{2}$ David Hilbert \& Wilhelm Ackermann, Grundzüge der theoretischen Logik, 1959. Cf. Amedeo Giovanni Conte, Ermeneutica dell'ambiguità, 1998; Paolo Di Lucia, L'universale della promessa, 1997; Paolo Di Lucia, Sollen in Herbert Spiegelberg, 2000.

3 Eike von Repgow, Sachsenspiegel, Reimvorrede, Verse 179-180 (Quedlinburger Handschrift, 1966, p. 12).

${ }^{4}$ Ludwig Wittgenstein, Bemerkungen über die Philosophie der Psychologie, 1980, Band II, $\S 535,95$.

English translation: "The expressed thought doesn't make a claim to being true, of correspondence of the affirmed state of affairs to a real state of affairs."

6 English translation: "Even clearer is the case of a normative statuition [Festsetzung], particularly of a statutory regulations. A normative statuition [Festsetzung], indeed, doesn't project a peculiar state of affairs (an order), but attribute to a state of affairs a way of existence which is called in German 'Geltung'."
} 


\subsection{The thetic function of the English modal verb shall}

\subsubsection{Deontic sense of shall vs. thetic function of shall in Herbert Spiegelberg}

The phenomenon of the pragmatic ambiguity occurs in the case of other linguistic forms which are prima facie deontic. In particular: the modal English verb 'shall' has not only a 'deontic sense'but also a 'thetic function' It has a deontic sense in sentences like:

(5) Thou shalt not kill,

whereas it has a thetic function in sentences like:

(6) All legislative powers shall be invested in Congress.

The idea of a thetic function of the English verb shall was formulated by Spiegelberg. In his words:

The shall-sentences, characteristic of all statutory regulations, set forth an order in which the referents of the subject and predicate are put into a new relationship, not yet determined by their natures: it takes the "shall" to bring it about. It "fixes" it by bestowing on it a certain artificial stability. [...] Without such an establishment this relation does not exist. It is the special act of ordering that establishes such an order.

(Spiegelberg 1935: 74; 1958: 244)

\subsubsection{Deontic sense of shall vs. thetic function of shall in EImer A. Driedger}

The semiotic status of shall-sentences is discussed in jurisprudence by Elmer A. Driedger [1913-1985]. Let us consider the sentence:

(7) There shall be a corporation.

According to Driedger, the shall-sentences form a paradigm case of a "creative shall", in which shall is used as a "non-obligatory auxiliary". In Driedger's own words,

this kind of a provision does not have continuing operation, and the present tense is therefore not suitable. It operates to create something the moment the words are spoken, and its force is then spent. The modern tendency, however, is to employ another expression, as, for example: "There is hereby established a corporation"

(Driedger 1976: 33). 


\section{Pragmatic ambiguity of verbal moods.}

\subsection{The thetic function of the Latin imperative mood.}

It is worth noting that the Latin future imperative mood has not only a deontic sense in sentences like:

(8) Estote parati,

but also a thetic function in sentences such as:

(9) Uti lingua nuncupassit, ita jus esto ${ }^{7}$

(10) Sacer esto,

(11) Dis sacer esto

and in sentences like:

(12) Heres esto.

According to Spiegelberg, the Latin future imperative, which is used in legislative texts, has two semantic peculiarities: non-deonticity and non-agentivity. In his own words:

Vgl. z. B. die Zwölftafelgesetze ('uti lingua nuncupassit, ita jus esto', 'dis sacer esto', 'se fraude esto' oder 'heres esto' in Testamenten); man beachte auch, daß in diesen Beispielen unmittelbar keinerlei Verhaltenspflichten festgesetzt werden; schon deswegen kann es hier nicht um Befehle handeln. (Spiegelberg 1935: 74, n.1) ${ }^{8}$

\subsection{The thetic function of the Latin subjunctive mood.}

The Latin subjunctive mood has not only a deontic sense (conjunctivus cohortativus) in sentences like:

(13) Gaudeamus igitur,

\footnotetext{
7 Ancient Roman Twelve Tables Code. Cfr. Paolo Di Lucia, Normatività. Diritto linguaggio azione, 2003, p. 61.

${ }^{8}$ English translation: "Cf. for instance, the Twelve Tables ("uti lingua nuncupassit, ita jus esto", "dis sacer esto", "se fraude esto" or "heres esto" in wills); these statuitions don't set forth a behavior-duty. Therefore they are no commands."
} 
(14) Alterius non sit qui suus esse potest,

but also a thetic function (conjunctivus constitutivus) in sentences like:

(15) Anathema sit,

(16) Fiat lux.

\section{References}

Amselek, Paul, ed. Théorie des Actes de Langage, Éthique et Droit. Paris: Presses Universitaires de France, 1986.

Bybee, Joan L. and William Pagliuca. The Evolution of Future Meaning. Amsterdam: John Benjamins, 1987.

Conte, Amedeo Giovanni. "Aspekte der Semantik der deontischen Sprache." In Deontische Logik und Semantik, edited by Amedeo Giovanni Conte, Risto Hilpinen and Georg Henrik von Wright, 59-73. Wiesbaden: Athenaion, 1977.

- . "Konstitutive Regeln und Deontik." In Ethik. Akten des Fünften WittgensteinSymposiums (Kirchberg am Wechsel 1980), edited by Edgar Morscher and Rudolf Stranzinger, 82-86. Wien: Hölder-Pichler-Tempsky, 1981.

—. "Ermeneutica dell'ambiguità." In Horizontes de la Hermenéutica, edited by Marcelino Agís Villaverde, 207-214. Santiago de Compostela: Universidade de Santiago de Compostela, 1998.

—. "Due specie di ambiguità nel linguaggio normativo. Ambiguità semantica vs. ambivalenza pragmatica." In Ricerche di filosofia del diritto, edited by Amedeo G. Conte, Paolo Di Lucia, Antonio Incampo, Giuseppe Lorini, Wojciech Zelaniec, and Lorenzo Passerini Glazel, 91-102. Turin: Giappichelli, 2006.

Conte, Maria-Elisabeth. "Epistemico, deontico, anankastico." In From Pragmatics to Syntax. Modality in Second Language Acquisition, edited by Anna Giacalone Ramat and Grazia Crocco Galèas, 3-9. Tübingen: Narr, 1995.

Daube, David. Forms of Roman Legislation. Oxford: Clarendon Press, 1956.

Di Lucia, Paolo. L'universale della promessa. Milan: Giuffrè, 1997.

-. "Sollen in Herbert Spiegelberg." In Linguistica giuridica/Rechtslinguistik, edited by Daniela Veronesi, 69-84. Padua: Unipress, 2000.

—. Normatività. Diritto linguaggio azione. Turin: Giappichelli, 2003.

Driedger, Elmer A. The Composition of Legislation. Legislative Forms and Precedents. Second edition. Ottawa: The Department of Justice, 1976.

Eckhardt, Karl August. Sachsenspiegel. Quedlinburger Handschrift. Hannover, Hahnsche Buchhandlung, 1966.

Eike von Repgow. Sachsenspiegel (Landrecht). Herausgegeben von Cl. Frhr. von Schwerin, Stuttgart: Reclam, 1987. 
Hedenius, Ingemar. Om rätt och moral. Stockholm: Tidens Förlag, 1941.

Hilbert, David and Wilhelm Ackermann. Grundzüge der Theoretischen Logik. Vierte Auflage, Berlin: Springer, 1959.

Lorini, Giuseppe, ed. Atto giuridico. Bari, Adriatica Editrice, 2000.

Sigwart, Christoph. Logik. Fünfte durchgesehene Auflage. Tübingen: Narr, 1924.

Spiegelberg, Herbert. Sollen und Dürfen. München, Bayerische Staatsbibliothek, (manuscript).

-. Gesetz und Sittengesetz. Strukturanalytische und historische Vorstudien zu einer gesetzesfreien Ethik. Zürich: Max Niehans, 1935.

-. Antirelativismus, Kritik des Relativismus und Skeptizismus der Werte und des Sollens. Zürich: Max Niehans, 1935.

-. "Zur Ontologie des idealen Sollens." Philosophisches Jahrbuch der GörresGesellschaft 66 (1958): 243-253.

-. Sollen und Dürfen. Philosophische Grundlagen der ethischen Rechte und Pflichten. Bearbeitet und herausgegeben von Karl Schuhmann. Dordrecht: Kluwer, 1989.

-. "Rules and order. Toward a phenomenology of order." In The Grinnell Symposium, edited by Paul Kuntz, 290-308. Washington: Washington University Press, 1968.

Watson, Alan. "The Imperatives of the Aedilician Edict." 1971. In: Studies in Roman Private Law, edited by Alan Watson, 333-343. London: The Hambledon Press, 1991, doi: 10.1163/157181971X00046.

Wittgenstein, Ludwig. Bemerkungen über die Philosophie der Psychologie. Oxford: Blackwell, 1980.

Wright, Georg Henrik von. Norm and Action. A Logical Enquiry. London: Routledge and Kegan Paul, 1963.

- . "Norms, truth and logic." In Practical Reason, edited by Georg Henrik von Wright, 130-209. Oxford: Blackwell, 1983.

\begin{abstract}
About the authors
Amedeo Giovanni Conte is member of Accademia Nazionale dei Lincei and professor emeritus at the University of Pavia. He is the author of: Saggio sulla completezza degli ordinamenti giuridici (Turin, Giappichelli, 1962); Filosofia del linguaggio normativo, III volumes, Turin, Giappichelli (1989-2001); Ricerche di filosofia del diritto (with Paolo Di Lucia, Giuseppe Lorini, Antonio Incampo, Wojciech Zełaniec, edited by Lorenzo Passerini Glazel, Turin, Giappichelli, 2006); Res ex nominee (Naples, Editoriale Scientifica, 2009); Adelaster. I nomi del vero (Macerata, Quodlibet, forthcoming).
\end{abstract}

Paolo Di Lucia is full professor of philosophy of law at the University of Milan (Italy) and invited professor at the Faculty of Theology of Lugano (Switzerland). He is the author of: Deontica in von Wright (Milan, Giuffrè, 1992); L'universale della 
DOI: $10.2478 / \mathrm{v} 10016-009-0009-7$

promessa (Milan, Giuffrè, 1997); Normatività. Diritto linguaggio azione (Turin, Giappichelli, 2003); Ontologia sociale. Potere deontico e regole costitutive (Macerata, Quodlibet, 2005); Ricerche di filosofia del diritto (with Amedeo Giovanni Conte, Giuseppe Lorini, Antonio Incampo, Wojciech Zełaniec, edited by Lorenzo Passerini Glazel, Torino, Giappichelli, 2006); Ens civile. Studi di ontologia (forthcoming). 